\title{
Molecular and Morphological Phylogenetic Analysis of Naupactus Dejean (Curculionidae: Entiminae) and Allied Genera: The Dilemma of Classification
}

\author{
Maria G. del Río ${ }^{1}$ (D), Marcela S. Rodriguero ${ }^{2}$, Viviana A. Confalonieri ${ }^{2}$ (i) and \\ Analía A. Lanteri ${ }^{1, *}$ \\ 1 División Entomología, Museo de la Plata, Facultad de Ciencias Naturales y Museo, Universidad Nacional de \\ La Plata, Paseo del Bosque s/n, B1900 FWA La Plata, Argentina; gdelrio@fcnym.unlp.edu.ar \\ 2 Departamento de Ecología, Genética y Evolución, Facultad de Ciencias Exactas y Naturales, Universidad de \\ Buenos Aires, IEGEBA (UBA-CONICET), Intendente Guiraldes y Costanera Norte s/n, 4o Piso, Pabellón II, \\ C1428EHA Ciudad Autónoma de Buenos Aires, Argentina; rodriguero@ege.fcen.uba.ar (M.S.R.); \\ bibilu@ege.fcen.uba.ar (V.A.C.) \\ * Correspondence: alanteri@fcnym.unlp.edu.ar; Tel.: +54-221-425-7744
}

Received: 31 May 2018; Accepted: 5 July 2018; Published: 10 July 2018

\begin{abstract}
Naupactus (Curculionidae: Entiminae) is the most speciose weevil genus of the tribe Naupactini. The main objective of this work is to recognize species groups within Naupactus and to analyze the relationships between this and other Neotropical genera. For this purpose, we compiled a combined data matrix of 60 terminal units corresponding to 40 species for which we recorded 812 molecular and morphological characters (763 and 49 respectively), which were analyzed by Maximum Parsimony and Bayesian analyses. The single tree obtained from each analysis was rooted with Cyrtomon inhalatus. The species of Naupactus were recovered as different monophyletic groups, some of them closer to other genera of Naupactini (Lanterius, Teratopactus, Pantomorus and Parapantomorus) than to species of the same genus. We conclude that Naupactus is non-monophyletic, even though most species can be recognized based on a particular combination of morphological characters, which are probably symplesiomorphic. To be consistent with the cladistic principles, some genera diversified in marginal areas of the Pantomorus-Naupactus complex should be synonymized with Naupactus; however, these nomenclatural changes may not ensure a generic definition based on synapomorphies. We prefer to be conservative about the current classification until more evidence is available. The only nomenclatural amendments proposed herein are the transference of Naupactus inermis Hustache to Lanterius and of N. setarius to Symmathetes.
\end{abstract}

Keywords: Neotropical region; broad-nosed weevils; Naupactini; Pantomorus-Naupactus complex; phylogeny; COI; combined evidence

\section{Introduction}

Naupactini is one of the most diverse tribes of broad-nosed weevils in the Neotropical Region [1,2]. It includes about 500 described species, several of them with agricultural importance, that probably represent half of its real diversity. This tribe may not be monophyletic in its present definition because it includes some genera from Africa, New Guinea, North America and an extinct genus from the Baltic Amber [3], which probably do not belong to this tribe. However, all the Neotropical genera and a few ranging also in the Nearctic region (e.g., Phacepholis Horn, Ericydeus Pascoe) [4,5] are likely to have a more recent common ancestor, as suggested by previous phylogenetic analyses based on morphological and combined data [2]. 
The generic definition of Naupactus has varied according to different authors [6-11]. For example, Morrone [12] includes in Naupactus most of the South American species traditionally placed in Pantomorus Schoenherr [13]. The actual number of species is uncertain due to the lack of a comprehensive revision. According to the last checklists of American weevils [12-14], there are more than 200 nominal species of Naupactus. However, it is possible that some of them should be synonymized because they are morphotypes, geographic races or males and females of the same species, others should be transferred to other genera of Naupactini, while many new species still remain to be described.

A preliminary phylogeny of 54 genera of Naupactini based on 69 terminal units (type species or species representative of these genera) and a set of 100 morphological characters suggests that there are three main clades (I, II and III), the latter being the most diversified in species and genera and divided into three major subclades (A, B and C) [2]. The analysis revealed that Naupactus belonged to clade III and the fact that the three species analyzed (types of genera considered synonyms of Naupactus) were distributed in subclades B and C would indicate that the genus is not monophyletic [2]. Likewise, phylogenetic analyses of a small set of Naupactus from South America [15] and from Central and North America [16] showed that the genus is not monophyletic, with species being placed close to the root of the tree.

In this study, we increased the sample size by adding more species of Naupactus and other genera of the Pantomorus-Naupactus complex [2,4,15-18] to recognize well-supported groups in an attempt to gain further insight into a natural generic classification of the naupactines. The recognition of natural groups (either genera or species groups) is essential to understand the evolution of certain characters, e.g., oviposition habits and parthenogenetic reproduction $[15,19]$ and for testing hypotheses about historical biogeography $[1,20]$.

The specific objectives of this contribution are as follows:

1. To recognize different groups of Naupactus and to analyze the relationships among them and with other genera of the Pantomorus-Naupactus complex: Aramigus Horn, Atrichonotus Buchanan, Eurymetopus Schoenherr, Floresianus Hustache, Galapaganus Lanteri, Hoplopactus Chevrolat, Lanterius Alonso-Zarazaga and Lyal, Pantomorus Schoenherr, Parapantomorus Emden, Phacepholis Horn, Symmathetes Schoenherr and Teratopactus Heller.

2. To test the monophyly of N. leucoloma Boheman species group [10] and N. xanthographus (Germar) species group [21].

\section{Materials and Methods}

\subsection{Taxon Sampling and Morphological Characters}

Samples of adult specimens were obtained from Argentina, Brazil, Ecuador, Uruguay, Mexico and Central America (Dominica Island). The new specimens included in this paper were collected from different areas of Argentina and Brazil; they were captured on wild and cultivated plants using a beating sheet or a sweeping net. The material was stored at $-80{ }^{\circ} \mathrm{C}$ or in $100 \%$ ethanol at $4{ }^{\circ} \mathrm{C}$ for molecular analysis. One leg of each specimen was removed for DNA sequencing. Most voucher specimens were deposited at the entomological collection of the Museo de La Plata, Argentina.

Externally visible and dissected structures were observed with a Nikon SMZ1000 stereomicroscope (Japan). For dissections we used standard entomological techniques [18]. The terminology used for morphological characters follows Marvaldi et al. [22], and Lanteri and del Rio [2].

We selected 58 specimens corresponding to 40 species and 12 genera of Naupactini recovered in Clade III, subclades B and C sensu Lanteri and del Río [2], plus species representative of two genera placed outside this clade, Cyrtomon Schoenherr and Litostylus Faust, which were used as outgroups. The taxon sampling includes almost all genera of the Pantomorus-Naupactus complex (except Alceis Billberg) and species of the main groups of Naupactus. For the phylogenetic analyses we consider only 
terminals for which COI sequences were available. Unfortunately, we were not able to get molecular sequences for the type species of Naupactus, N. rivulosus (Olivier) from South America.

The complete valid names, acronyms, geographic data and accession numbers for the terminal units are given in Table 1. Some species are represented by more than one specimen because they show different morphotypes and/or haplotypes.

Table 1. List of the 60 terminal taxa included in the phylogenetic analysis of the tribe Naupactini, valid names, acronyms used in the analysis, geographic data and genbank accession numbers and source for the terminal units. * The acronyms of Lanterius inermis and Symmathetes setarius correspond to the species names previous to the nomenclatural actions taken in this work.

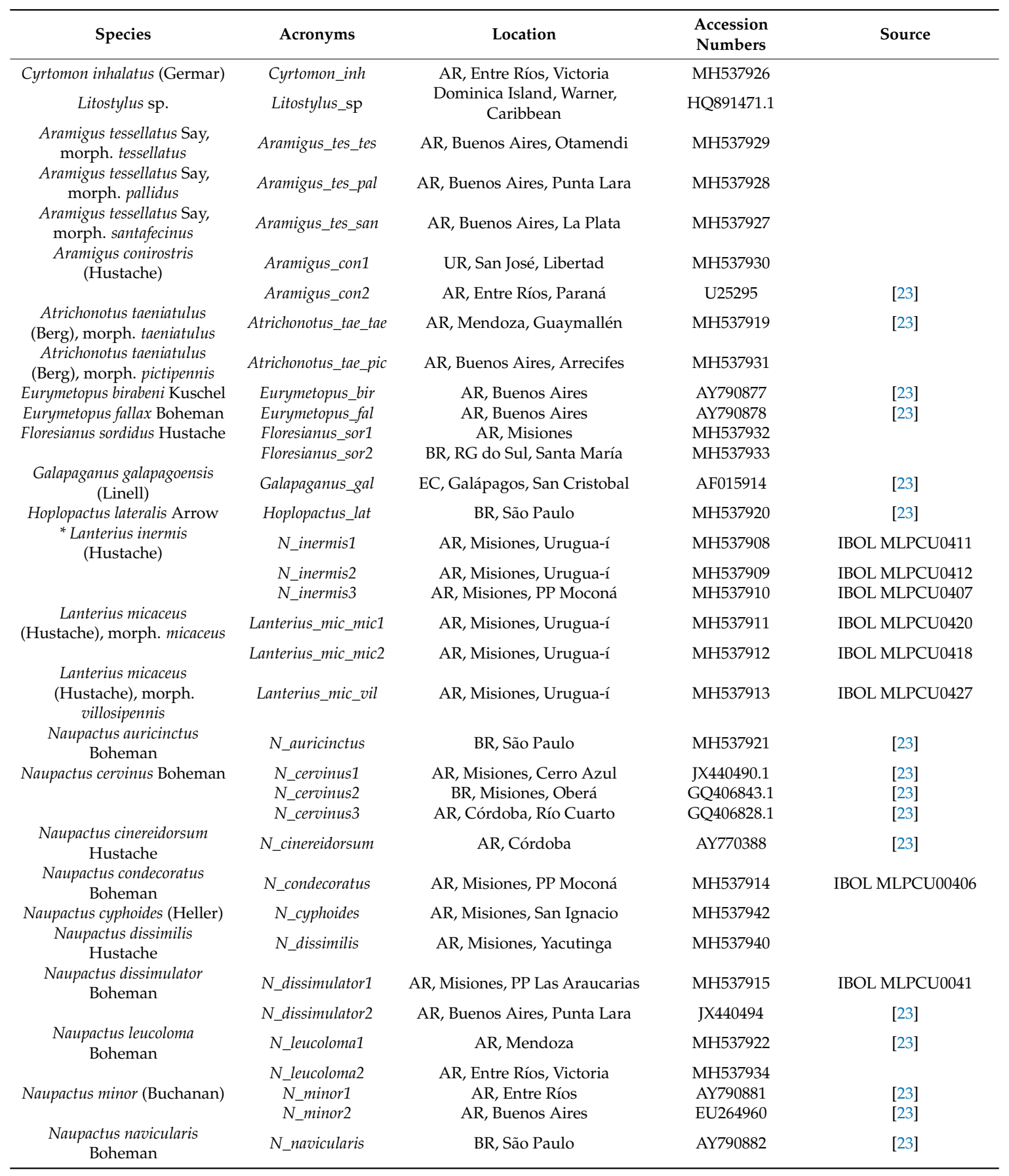


Table 1. Cont.

\begin{tabular}{|c|c|c|c|c|}
\hline Species & Acronyms & Location & $\begin{array}{l}\text { Accession } \\
\text { Numbers }\end{array}$ & Source \\
\hline $\begin{array}{l}\text { Naupactus peregrinus } \\
\text { (Boheman) }\end{array}$ & N_peregrinus & AR, Entre Ríos, Concordia & MH537935 & \\
\hline $\begin{array}{c}\text { Naupactus purpureoviolaceus } \\
\text { Hustache }\end{array}$ & N_purpureoviolaceus & AR, Entre Ríos, Concordia & MH537936 & \\
\hline Naupactus stupidus Boheman & N_stupidus & ME, Oaxaca, Salina Cruz & GU565274 & [23] \\
\hline $\begin{array}{c}\text { Naupactus sulfuratus } \\
\text { Champion }\end{array}$ & N_sulfuratus & ME, Oaxaca, Salina Cruz & GU565270 & [23] \\
\hline $\begin{array}{c}\text { Naupactus tremolerasi } \\
\text { Hustache }\end{array}$ & N_tremolerasi & BR, RG do Sul, Santa María & MH537937 & \\
\hline $\begin{array}{l}\text { Naupactus tucumanensis } \\
\text { Hustache }\end{array}$ & N_tucumanensis & AR, Tucumán & MH537938 & \\
\hline $\begin{array}{l}\text { Naupactus verecundus } \\
\text { Hustache }\end{array}$ & N_verecundus & AR, La Pampa, Santa Rosa & AF211490 & [23] \\
\hline Naupactus versatilis Hustache & $\begin{array}{l}\text { N_versatilis1 } \\
\text { N_versatilis2 }\end{array}$ & $\begin{array}{c}\text { AR, CABA } \\
\text { AR, Misiones, Teyú Cuaré }\end{array}$ & $\begin{array}{l}\text { MH537939 } \\
\text { MH537916 }\end{array}$ & IBOL MLPCU0117 \\
\hline $\begin{array}{c}\text { Naupactus xanthographus } \\
\text { (Germar) }\end{array}$ & N_xanthographus & AR, Buenos Aires, Punta Lara & AY790880.1 & [23] \\
\hline Pantomorus auripes Hustache & Pantomorus_aur & AR, Córdoba & AY770383 & [23] \\
\hline $\begin{array}{l}\text { Pantomorus cinerosus } \\
\text { (Boheman) }\end{array}$ & Pantomorus_cin & AR, Córdoba & AY770384 & [23] \\
\hline $\begin{array}{c}\text { Pantomorus postfasciatus } \\
\text { (Hustache) (misidentified as } \\
\text { N. ambiguus [23]) }\end{array}$ & Pantomorus_pos1 & AR, Chaco, Resistencia & MH537917 & \\
\hline Pantomorus ruizi (Brèthes) & $\begin{array}{l}\text { Pantomorus_pos2 } \\
\text { Pantomorus_rui1 } \\
\text { Pantomorus_rui2 }\end{array}$ & $\begin{array}{l}\text { BR, RG de Sul, Santa Maria } \\
\text { AR, Chubut, Trelew } \\
\text { AR, La Pampa }\end{array}$ & $\begin{array}{l}\text { MH537918 } \\
\text { MH537925 } \\
\text { AY770385 }\end{array}$ & $\begin{array}{l}{[23]} \\
{[23]}\end{array}$ \\
\hline $\begin{array}{l}\text { Pantomorus viridisquamosus } \\
\text { (Boheman) }\end{array}$ & Pantomorus_vir & AR, Buenos Aires & AY770386 & [23] \\
\hline $\begin{array}{c}\text { Parapantomorus fluctuosus } \\
\text { (Boheman) }\end{array}$ & Parapantomorus_flu & BR, São Paulo & MH537941 & \\
\hline Phacepholis albicans (Sharp) & Phacepholis_alb & ME, Gerrero, Tecpan & GU565278 & [23] \\
\hline $\begin{array}{c}\text { Phacepholis globicollis } \\
\text { (Pascoe) }\end{array}$ & Phacepholis_glo & ME, Oaxaca, Salina Cruz & GU565273 & [23] \\
\hline Phacepholis viridicans (Sharp) & Phacepholis_vir & ME, Jalisco, Chamela & GU565277 & [23] \\
\hline $\begin{array}{l}\text { *Symmathetes setarius } \\
\text { (Boheman) }\end{array}$ & N_setarius & BR, Mato Grosso & MH537923 & [24] \\
\hline $\begin{array}{c}\text { Symmathetes setulosus } \\
\text { Hustache }\end{array}$ & Symmathetes_setu & AR, Catamarca, Las Esquinas & MH537924 & [24] \\
\hline $\begin{array}{l}\text { Teratopactus nodicollis } \\
\text { (Boheman) }\end{array}$ & Teratopactus_nod & BR, São Paulo & AY770387 & [15] \\
\hline
\end{tabular}

For each terminal, we recorded data for 49 discrete morphological characters, of which 37 correspond to external morphology and 12 to female and male genitalia; 35 characters are coded as double state (binary) and 14 as multistate. The list of morphological characters is given in Table 2 and the data matrix is shown in Table S1. When genitalia could not be examined (mainly because males are unknown), character states were scored with '?' and treated as missing data. For the illustrations of several characters, particularly those of male and female genitalia, see Lanteri and del Rio [2]. The acronyms used to describe the shape of the rostrum are as follows: WF, maximum width of forehead; WR, width of rostrum at apex excluding borders of scrobes.

The combined data matrix includes 60 terminal units by 812 characters ( 49 morphological and 763 molecular). 
Table 2. List of the 49 morphological characters, character states and codes.

0. Rostrum, lateral margins: subparallel to slightly convergent anteriad (WF/WR less than $1.25 \times)(0)$; moderately convergent anteriad (WF/WR 1.25-1.50×) (1); strongly convergent anteriad (WF/WR more than $1.50 \times)(2)$.

1. Rostrum, lateral carinae: absent (0); present (1).

2. Mouthparts, prementum, long setae on external face: present (0); absent (1).

3. Rostrum, anteocular impression: distinct (0); indistinct (1).

4. Head, eyes: flat (0); convex (1); strongly convex (2); conical (3).

5. Head, post-ocular constriction: absent to very slight (0); present (1).

6. Antennae, shape of scape: clavate, broad (0); slightly capitate, slender (1).

7. Antennae, length of scape: not reaching hind margin of eye (0); reaching to exceeding hind margin of eye (1).

8. Antennae, relative length of funicle antennomeres 1 and 2: funicle antennomere 2 about as long as antennomere 1 (0); funicle antennomere 2 more than $1.5 \times$ longer than antennomere 1 (1).

9. Antennae, length of funicle antennomeres 4 to 7 : distinctly longer than wide (0); about as long as to slightly longer than wide (1).

10. Pronotum, shape: subconical (0); subcylindrical (1).

11. Pronotum, convexity of disc (males): flat to slightly convex (0); strongly convex (1).

12. Pronotum, lateral longitudinal impressions: present (0); absent (1).

13. Pronotum, lateral tubercles: absent (0); present (1).

14. Pronotum, macrosculpture of surface: irregularly shaped and connected fovae (0); granulose (1); slightly granulose to smooth (2).

15. Scutellum, vestiture: present (0); absent (1).

16. Elytra, shape of scales: rounded (0); oval (1); piliform (2).

17. Elytra, setae: recumbent (0); erect (1).

18. Elytra, white, obliquely ascending stripes, on sides on posterior third: absent (0); present (1).

19. Elytra, white stripes along intervals 6 to 8: absent (0); present (1).

20. Elytra, brown, rectangular maculae on middle length of interval 3: absent (0); present (1).

21. Elytra, outline of base: strongly bisinuate (0); slightly bisinuate (1); straight (2).

22. Elytra, development of humeri: well-developed (0); reduced (1); absent (2).

23. Elytra, humeral tubercle: absent (0); present (1).

24. Elytra, declivity of disc: slightly to strongly ascending towards declivity (0); elytral disc not ascending towards declivity (1).

25. Elytra, height in lateral view: high (0); flat (1).

26. Elytra, proximity of striae 9 and 10: striae 9 and 10 confluent along posterior $2 / 3$ (0) striae 9 and 10 slightly closer to each other along posterior $2 / 3$ (1).

27. Elytra, presence of apical tubercles: absent (0); present (1).

28. Legs, separation of front coxae from each other (females): contiguous (0); separated from each other (1).

29. Legs, width of front femora less than $1.5 \times$ as wide as hind femora (0); more than $1.5 \times$ as wide as hind femora (1).

30. Legs, denticle on front femora: absent (0); present (1).

31. Legs, row of denticles on inner edge of tibiae: absent to indistinct in all tibiae (0); present in front tibiae only (1); present in the three pairs of tibiae (2).

32. Legs, mucro of tibiae: present only on front tibiae (0); present on front and middle tibiae (1).

33. Legs, metatibial apex: not to slightly widened (0); distinctly widened (apex about $1.5-2 \times$ as wide as minimum width of tibia) (1).

34. Legs, corbel at metatibial apex: well-developed (0); indistinct, metatibial apex thickened (1); absent (=metatibial apex simple) (2).

35. Legs, relative length of combs at metatibial apex: dorsal comb distinctly longer than distal comb (0); dorsal and distal comb about same length (1); dorsal comb shorter than distal comb (2).

36. Venter, denticles on ventrite 2 of male: absent (0); present (1).

37. Female terminalia, shape of sternite VIII (plate): subrhomboidal, not elongate (0); subrhomboidal, very elongate (1); suboval (2); subpentagonal (3).

38. Female terminalia, length of ovipositor (distal plus proximal gonocoxites): ovipositor shorter than abdominal length (0); equal to slightly longer than abdominal length (1). 
Table 2. Cont.

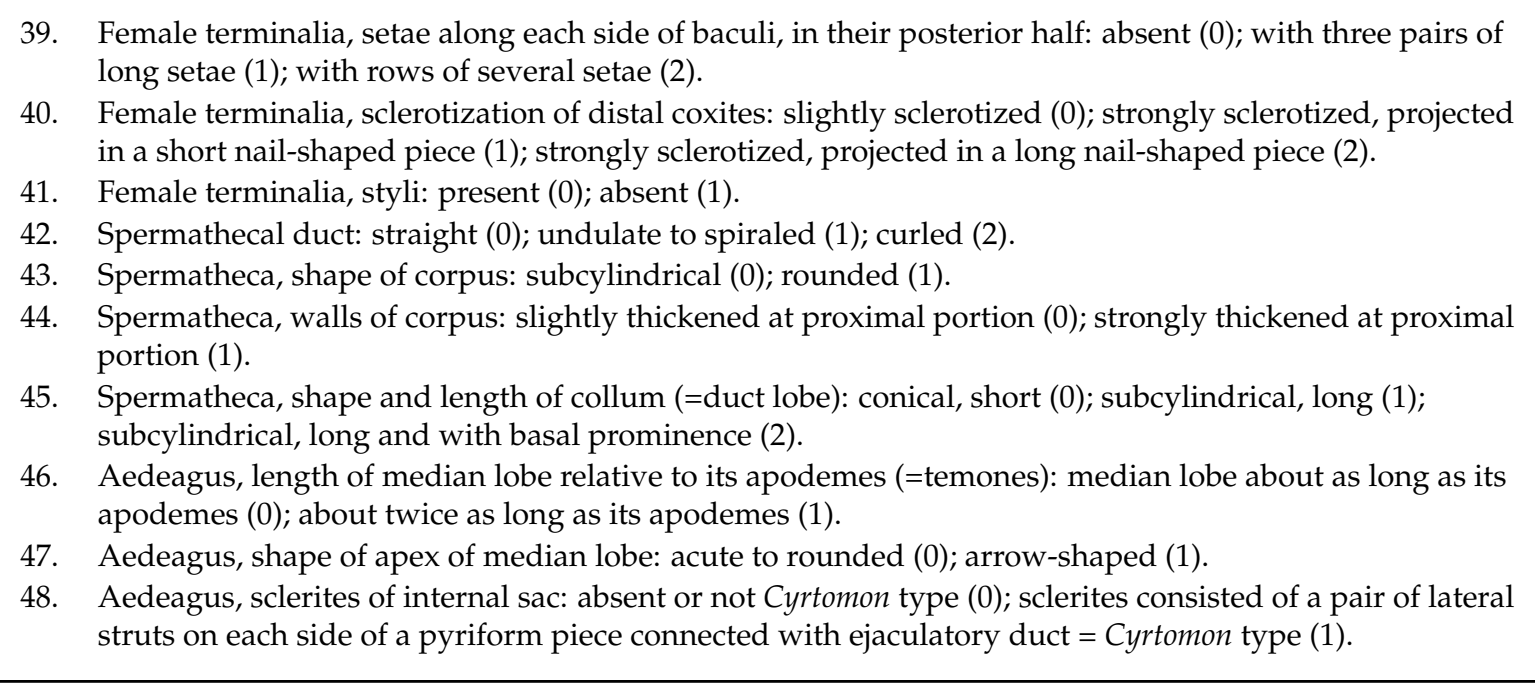

\subsection{Molecular Data: DNA Assay and Sequencing}

Cytochrome Oxidase I (COI) was chosen as molecular marker because is the most commonly used in Naupactini for analyses at species level. COI sequences derived from different sources. Most of them were obtained at the Instituto de Ecología, Genética y Evolución, Buenos Aires (IEGEBA-CONICET/UBA), or at the Biodiversity Institute of Ontario, University of Guelph, Canada, and they are available at the Barcode of Life Data Systems (BOLD) [23], Invertebrates from Argentina project, with the participation of A. Lanteri and M.G. del Río. Other sequences have already been published by some of us [15,16,24-27], and one sequence was downloaded from GenBank (see Table S1).

The DNA assayed at the IEGEBA-CONICET/UBA was extracted following the protocol of Sunnucks and Hales [28]. The COI mitochondrial gene was amplified using the following primers designed by Normark [29]: S1718 (5'-GGA GGA TTT GGA AAT TGA TTA GTT CC-3') and A2442 (5'-GCT AAT CAT CTA AAA ATT TTA ATT CCT GTT GG-3').

Amplification was carried out in a total volume of $50 \mathrm{uL}$ with 50-100 ng of DNA used as template, $0.5 \mathrm{uM}$ of each primer (Thermo Scientific, Rockford, IL, USA), $0.1 \mathrm{mM}$ of each dNTP (Promega, Madison, WI, USA), 1.0 unit of Taq polymerase, $3.0 \mathrm{mM} \mathrm{MgCl}_{2}$ and $1 \times$ reaction buffer (Thermo Scientific, Rockford, IL, USA). Amplifications were performed in a thermal cycler GeneAmp PCR System 2700 (Applied Biosystems, Inc., Gaithersburg, MD, USA) under the following conditions: $94{ }^{\circ} \mathrm{C}$ for $1 \mathrm{~min}, 35$ cycles at $94{ }^{\circ} \mathrm{C}$ for $1 \mathrm{~min}, 46^{\circ} \mathrm{C}$ for $1.5 \mathrm{~min}$, and $72{ }^{\circ} \mathrm{C}$ for $1.5 \mathrm{~min}$, and a final extension at $72{ }^{\circ} \mathrm{C}$ for $5 \mathrm{~min}$. Each series of amplifications included a negative control with no template DNA. Double-stranded PCR products were separated by electrophoresis on a $1 \%$ agarose gel with TAE buffer containing GelRed TM (GenBiotech, Buenos Aires, Argentina). The PCR products were purified using an AccuPrep purification kit (Bioneer, Daejeon, Korea). DNA was sequenced using a 3130-XL Automatic Sequencer (Applied Biosystems, Inc., Foster City, CA, USA) at the Unidad de Secuenciación y Genotipificado (FCEyN, UBA, Buenos Aires, Argentina). The sequences obtained have been entered into GenBank under the accession numbers MH537908-42.

To avoid amplification of COI pseudogenes [30], sequences were translated according to the invertebrate mitochondrial genetic code in MEGA v. 5 [31] and examined using as reference amino acid sequences obtained for several insect orders [32]. A copy containing no frame-shifts or stop codons was assumed to be mitochondrial [33,34]. Sequence alignment was done using CLUSTAL W [35].

The molecular data matrix included $763 \mathrm{bp}$ of the mtDNA COI gene corresponding to positions 210-973. 


\subsection{Phylogenetic Analyses}

The combined and molecular data sets were analyzed using Maximum Parsimony (MP) and Bayesian approaches. For the MP method, a heuristic search with TBR branch swapping was applied to a series of 500 random addition sequences, retaining 30 trees per replicate, using TNT v1.5 [36]. Clade stability was evaluated by 1000 parsimony bootstrap replications [37] and support values over $40 \%$ were mapped onto internal nodes of the tree. All characters were considered as un-weighted and non-additive. For the MP trees we provided the total length (L), consistency index (CI) [38] and retention index (RI) [39].

The Bayesian analysis was performed using BEAST2 v2.4.8 [40] on Cipres Science Gateway (http:/ / www.phylo.org) [41] with random starting trees without constraints. The optimal substitution model was selected using the jModeltest software v2.0 [42], on the basis of the corrected Akaike Information Criterion, as suggested by Burnham and Anderson [43]. We applied the substitution models GTR + I + G and Lewis MK for COI and morphological data, respectively. We assumed a Yule speciation model and strict molecular clock. Clock and tree parameters were linked across partitions. All priors were left as the default values in BEAUTI [40]. The analyses were run for a total of 30 million generations with sampling every 10,000 generations. The convergence of the runs was evaluated by accessing log files in TRACER v1.6 [44]. We generated a maximum clade credibility tree in TreeAnnotator v2.4.8 [40], using a burn-in of 10\% (3000 trees) and visualized in FigTree v1.4.3 [45].

The trees obtained from both analyses were rooted with Cyrtomon inhalatus (Germar) (Naupactini clade II sensu Lanteri and del Rio [2]).

\section{Results}

\subsection{Bayesian Analysis}

The tree obtained from the Bayesian analysis is shown in Figure 1. Clades with posterior probabilities $\geq 0.95$ are indicated in boldface. Litostylus was recovered as the sister genus of the remaining taxa (PP 0.8). The species groups of Naupactus are spread into four main clades of the tree, with PP values $\geq 0.50$ : clade A includes the pair $N$. stupidus $-N$. sulfuratus (PP 1); clade B includes the majority of species, with N. tucumanensis to N. versatilis (PP 1) as sister group of Hoplopactus-anterius-N. inermis; clade $C$ includes the pair N. cinereidorsum-N. cyphoides related to Teratopactus; and clade D includes the species usually classified as belonging to genera other than Naupactus, except for the group ( $(N$. dissimilis-N. xanthographus) N. navicularis) (PP 1), N. cervinus-N. dissimulator (PP 1), and N. setarius.

The combined approach provided strong evidence for the monophyly of the genera Aramigus, Eurymetopus and Phacepholis, but this would not the case for Pantomorus. In addition, well-supported nodes proved intergeneric relationships for Galapaganus-Phacepholis, and Eurymetopus-Floresianus to be robust. The best supported group within Pantomorus is P. auripes-P. ruizi (PP 0.98).

The terminal units regarded as the same species are recovered in the same groups, despite their different geographic origins, sex or morphotypic variation. For example, the two females of Lanterius micaceus belonging to the micaceus morphotype (originally described as Mimographus micaceus) are grouped with the male of villosipennis morphotype (originally described as M. villosipennis) (synonymy by Lanteri, 1985 [46]). Similarly, the two morphotypes of Atrichonotus taeniatulus (taeniatulus and pictipennis) [18], originally described as different species, are recovered as conspecific.

The length of the branches of the Bayesian tree indicate a very high infraspecific variation in the parthenogenetic species Aramigus tessellatus, A. conirostris and N. cervinus, which show several divergent lineages and/or cryptic species [26,47]. 


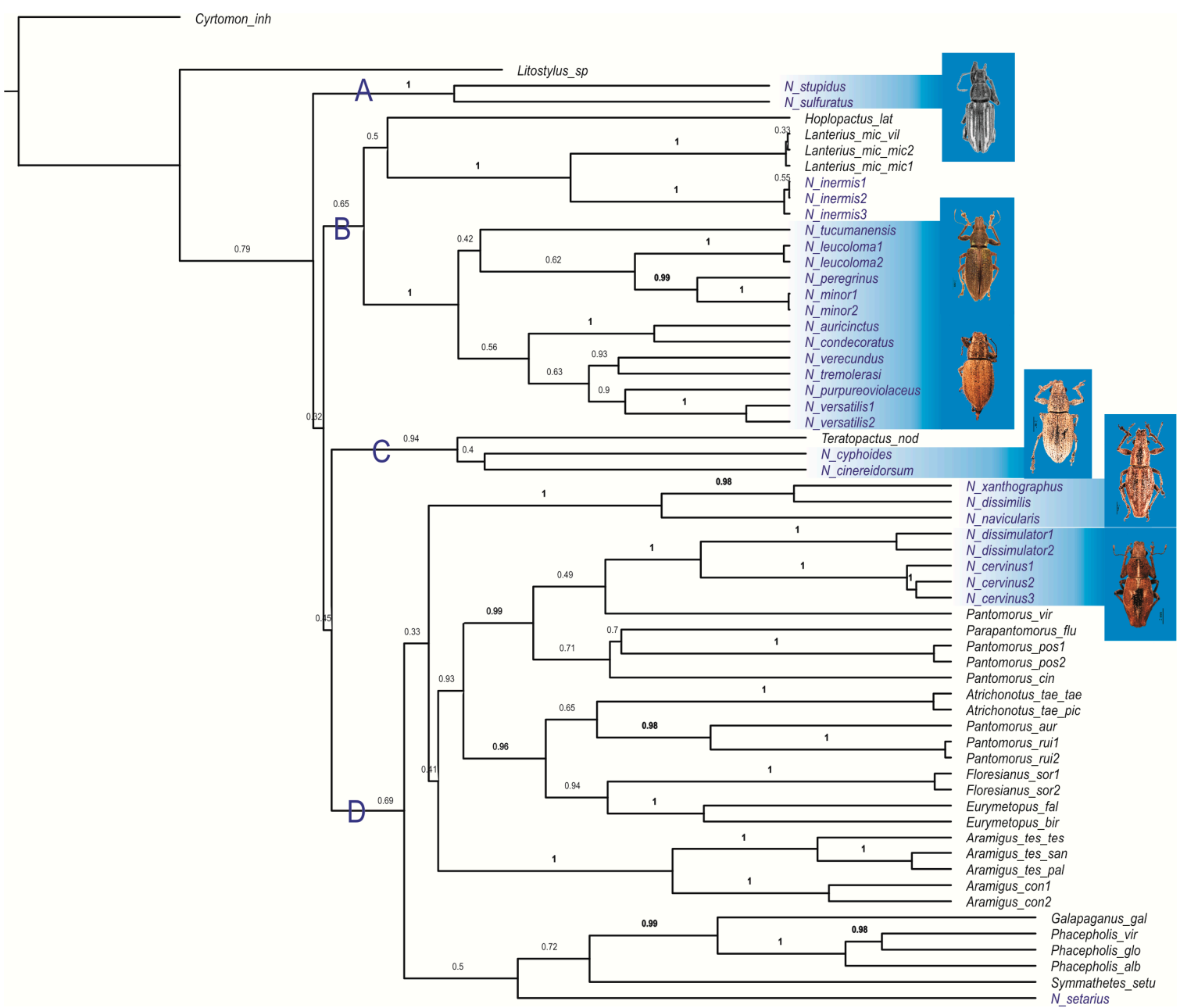

Figure 1. Tree obtained by Bayesian analysis (MCC) from a data matrix of 60 terminal units of Naupactini by 812 characters. Posterior probabilities $\geq 0.95$ are indicated in boldface. The groups of Naupactus are highlighted in blue and illustrated. 


\subsection{Parsimony Analysis}

The Parsimony analysis of the combined data set yielded four most parsimonious trees $(\mathrm{L}=2457$ steps; $\mathrm{CI}=0.52 ; \mathrm{RI}=0.27$ ) (Figure 2), which best support the same monophyletic groups as the Bayesian tree. There are changes in the relationships among some weakly supported groups and unstable species: (1) the pair N. sulfutatus-N. stupidus is recovered in the same clade as Galapaganus-Phacepholis; (2) the group N. auricinctus to N. tucumanensis is strongly supported, but the interspecies relationships within it are slightly different from those in the Bayesian tree; (3) N. cinereidorsum, N. cyphoides and Teratopactus are recovered in the same clade as N. navicularis (N. xanthographus-N. dissimilis), and Aramigus; (4) Naupactus setarius + S. setulosus are sister species within a large clade that includes the pair N. dissimulator-N. cervinus and species of other genera (Pantomorus, Parapantomus, Atrichonotus, Floresianus and Eurymetopus).

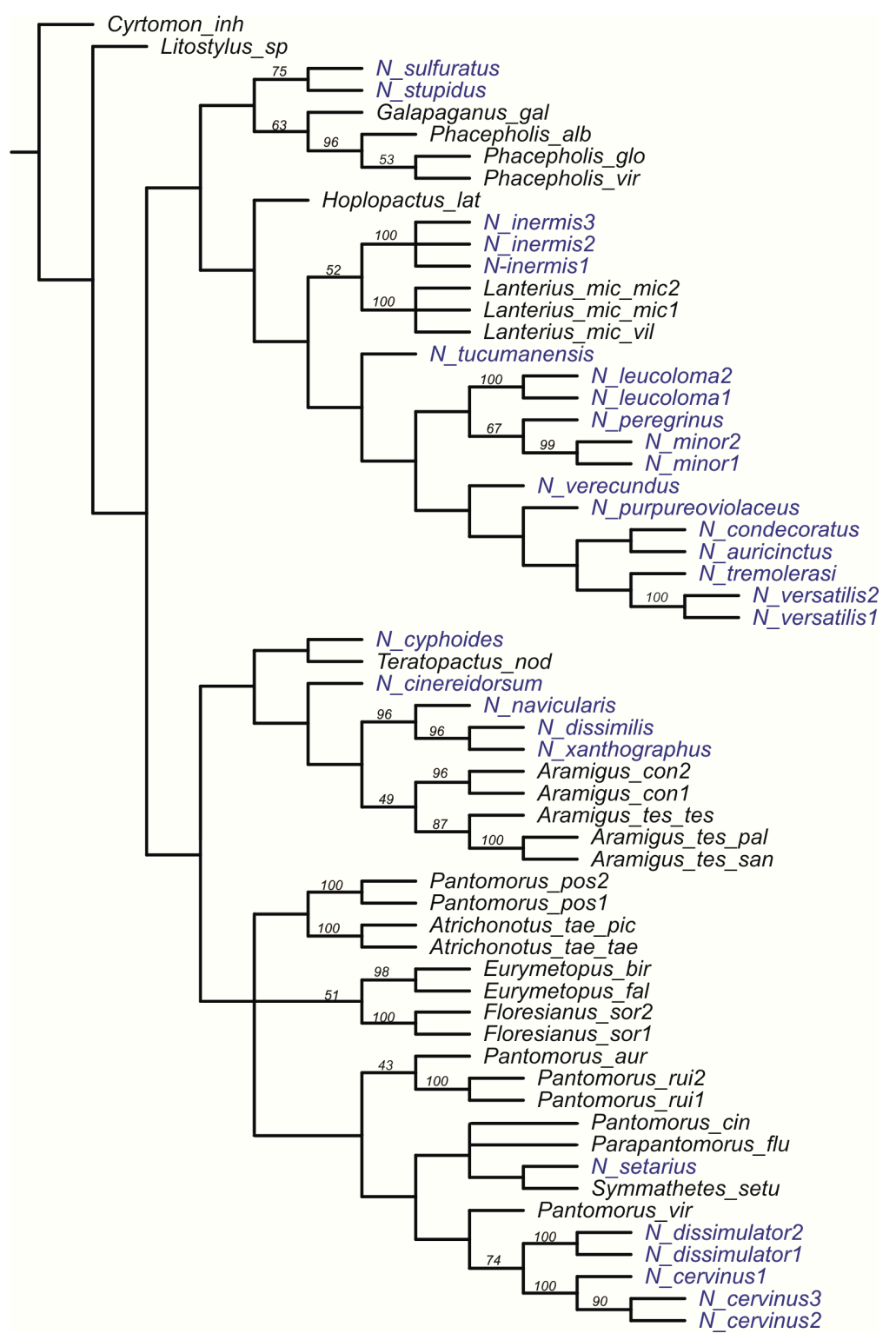

Figure 2. Strict consensus tree obtained by parsimony analysis from a data matrix of 60 terminal units of Naupactini by 812 characters. Bootstrap values $\geq 40$ are indicated onto branches. The species of Naupactus are highlighted in blue. 


\section{Discussion}

Naupactus is recognized by a particular combination of characters, which is useful for the generic identification but misses out exclusive synapomorphies, e.g., the presence of rows of setae along the ovipositor is a derived character for Naupactini, but also occurs in other genera such as Lanterius. Moreover, this feature is lacking in some species of the same genus, e.g., the Central American N. sulfuratus and N. stupidus. The most diagnostic characters of Naupactus are: parallel-sided rostrum, orientated anteriad and with strong lateral carinae; long antennae with funicular antennomere 2 distinctly longer than antennomere 1; wide pronotum, elevated over the mesothoracic peduncle, lacking tubercles; squamose scutellum; moderately bisinuate to straight elytral base; well-developed to reduce humeri, lacking tubercles; fully-developed to reduce hind wings; slightly separate to contiguous front coxae; front femora distinctly wider than hind femora, lacking large denticles or spines; mucro and row of denticles usually present on inner margin of front tibiae; metatibial apex having broad to slender squamose corbel or lacking corbel; penis without flagellum; proximal half of spermatheca with strongly thickened walls, collum (=duct lobe) usually short and ramus indistinct; ovipositor usually not exceeding length of abdomen, bearing styli and rows of long setae along its posterior two-thirds.

Clade A corresponds to the sister species $N$. sulfuratus and N. stupidus, which are the only Naupactus from Central America included in our taxon sampling. In the MP tree these species are closer to other Central American or Northern South American naupactines (e.g., Phacepholis and Galapaganus). Additional information suggests that they might be related to some Naupactus from northern South America not included in our analyses, e.g., N. instabilis Boheman (from Colombia and Venezuela) and N. litoris Bordón (from Venezuela).

Naupactus of clade B are more closely related to Lanterius and Hoplopactus than to other Naupactus in both analyses. Indeed, $N$. inermis was recovered as a sister species of Lanterius micaceus. Consequently, we decided to transfer $N$. inermis to Lanterius, a genus that mainly differs from Naupactus in its smaller body size, slender pronotum, not elevated over the thoracic peduncle, and the 9 and 10 elytral striae separated along their posterior two-thirds. Hoplopactus differs from Lanterius and Naupactus by a distinct apomorphic character, namely the presence of one to three spines on the inner margin of front femora. Neither Lanterius nor Hoplopactus have yet been taxonomically revised.

The group $N$. tucumanensis to $N$. versatilis is well supported by the combined evidence and includes two weakly supported subgroups: $N$. auricintus to $N$. versatilis is mainly characterized by the undulate to spiraled spermathecal duct, and N. tucumanensis to N. minor is recognized by a particular color pattern of white stripes along sides of pronotum and elytra, and the penis about $\frac{1}{2}$ longer than its apodemes. The second subgroup corresponds to N. leucoloma species group sensu Lanteri and Marvaldi [10] described for the white-fringed weevils N. leucoloma, N. minor, N. peregrinus, $N$. tucumanensis and $N$. albolateralis. The relationship $N$. peregrinus $-N$. minor is strongly justified (PP 0.99). Scataglini et al. [15] recovered the sister relationship N. leucoloma-N. minor, but the species N. peregrinus and N. tucumanensis were not available for that analysis.

Clade $C$ includes the sister species $N$. cinereidorsum-N. cyphoides and Teratopactus. The type species of Naupactus, N. rivulosus, would belong to this group [48]. Teratopactus occurs in similar environments (woodlands and savannas) and mainly differentiates from the typical Naupactus by the apomorphies of the tubercles at the humeri and, in some cases, on the sides of pronotum; the front coxae separated from each other; the styli of the ovipositor usually lacking, and the distal coxites transformed into strong nail-like pieces adapted to oviposition of isolated eggs in the soil [49].

Clade D includes the species of Naupactus assigned to the N. xanthographus species group, mainly characterized by the presence of one pair of tubercles at the apex of the elytra [21], N. cervinus and N. setarius, plus those of some genera other than Naupactus (Aramigus, Atrichonotus, Pantomorus, Parapantomorus, Floresianus, Eurymetopus, Galapaganus, Phacepholis and Symmathetes). Within the N. xanthographus species group Lanteri \& del Río [21] recognized two subgroups: one comprising $N$. xanthographus, $N$. navicularis, $N$. dissimilis and $N$. mimicus, having well-developed, squamose corbels at the metatibial apex, and the other composed of $N$. dissimulator and $N$. marvaldiae, without corbels. 
In our trees, these subgroups are recovered as independent lineages. The former subgroup shows unstable relationships, as evidenced by the different results from the Bayesian and MP trees. Naupactus dissimulator is always recovered as sister species of $N$. cervinus based on molecular data and some synapomorphies of the female and male genitalia (e.g., shape of spermatheca and sclerites of the internal sac of the penis). The latter species lacks the pair of tubercles at the apex of the elytra, typical of the N. xanthographus species group, suggesting that these tubercles evolved independently at least twice in the genus Naupactus and were lost in N. cervinus.

Naupactus cervinus is a species complex containing divergent parthenogenetic lineages and cryptic species [26]. It has been classified in Naupactus [3], Pantomorus [13,14] and Asynonychus (type species A. godmanni Crotch, junior synonym of $N$. cervinus) [12,50] and according to previous analyses its phylogenetic position is uncertain. It was placed close to Aramigus when only morphological characters were used [2], while it was recovered as the sister species of $N$. dissimulator when molecular information was added [15]. In this work we confirm its relationship with $N$. dissimulator, although additional taxonomic information suggests that might be closer to some species not included in our analysis, such as N. marvaldiae [21] and other undescribed naupactines close to Alceis, considered as a synonym of Naupactus in some old classifications [51].

The South American Pantomorus herein analyzed (classified as Naupactus in Morrone [12]) do not form a monophyletic group. The pair P. auripes + P. ruizi is recovered in the same group as Atrichonotus, Floresianus and Eurymetopus, and the remaining Pantomorus and Parapantomorus, in the group that includes $N$. cervinus $-N$. dissimulator. As in the case of $N$. cervinus, we guess that several naupactines from South America alternatively classified in Pantomorus, Parapantomorus or Naupactus, belong to or are more closely related to Alceis. Unfortunately, the available molecular information and the taxon sampling are insufficient to take a definite decision about the correct placement of these taxa.

Aramigus (South America) and Phacepholis (Central and North America), considered subjective synonyms of Pantomorus in some classifications (e.g., [13,51] and later revalidated [4,52], are monophyletic genera, which is in agreement with previous phylogenetic analyses [16,47]. They are grouped neither together nor with other Pantomorus, thus supporting the hypothesis that Pantomorus sensu Wibmer and O'Brien [13] is not monophyletic. Aramigus is not close to any particular group of South American Pantomorus or Naupactus, included in our analysis, whereas Phacepholis is related to Galapaganus [53,54]; however, in previous analysis [2,16], Phacepholis is more related to the Central American Pantomorus (the type species P. albosignatus Boheman from Mexico). We believe that the latter hypothesis is more plausible and that it was retrieved closer to Galapaganus because of the absence of species from that area.

Symmathetes was also considered as a synonym of Pantomorus in earlier classifications $[13,51]$ and latter revalidated [12]. In our MP tree and in the MP tree using four molecular markers [24], N. setarius was recovered as sister species of Symmathetes setulosus, consequently we propose to transfer the former species to Symmathetes and to establish the new combination Symmathetes setarius (Boheman). This species is very similar to the type species $S$. kollari Schoenherr except for its flat eyes. Symmathetes mainly characterizes by the expanded metatibial apex, split off in $S$. kollari and S. setarius.

Eurymetopus is monophyletic and related to Floresianus, based on several morphological synapomorphies and also supported by molecular evidence [15]. Although grouped within the same clade, Atrichonotus is not recovered as sister taxon of the pair Eurymetopus-Floresianus as in Lanteri and del Río [2]. The fact that some species show intermediate characters between Atrichonotus and Eurymetopus, e.g., Atrichonotus whiteheadi Lanteri [55], suggests that the three genera are related.

\subsection{Taxonomic Implications of Phylogenetic Analyses}

The Pantomorus-Naupactus complex includes several lineages with derived characters, such as shorter and more conical rostrum, shorter antennae, reduced to absent hind wings and parthenogenetic reproduction, which might have evolved several times, thus obscuring phylogenetic signal and leading to high degrees of homoplasy $[2,15,56]$. Pantomorus sensu lato (including species from different areas 
of North, Central and South America) is an example of a non-monophyletic genus diversified in new adaptive zones or marginal areas within the range of this complex. Other groups undergoing diversification in marginal areas would have acquired exclusive synapomorphies, allowing the recognition of monophyletic genera, e.g., Phacepholis would have diversified along the western coast of Central America and the Great Plains of North America, and it is recognized by the particular shape of the spermatheca and the presence of a series of small denticles on the second ventrite of the male [4,16,20]; Aramigus and Eurymetopus have acquired several synapomophies in the female genitalia (particular shape of spermatheca, sternite VIII or ovipositor) and would have diversified in grasslands and steppes of South America [18,52,57]; and Galapaganus, which displays synapomorphies in the male genitalia (setae around the ostium), would have diversified along the western coast of South America and the Galapagos Islands $[24,53,54,58,59]$.

The result obtained herein raises the dilemma that the recognition of several genera within the Pantomorus-Naupactus complex leads Naupactus to be non-monophyletic. Morrone [12] made an attempt to solve this problem by transferring all the South American species of Pantomorus to Naupactus, in a checklist based on neither revisionary nor phylogenetic studies. However, these nomenclatural changes did not solve the problem of the monophyly of Naupactus, but instead they created a large genus very difficult to circumscribe. According to our analysis, if Naupactus is monophyletic, it may include not only the South American Pantomorus but also Hoplopactus, Lanterius, Teratopactus, Aramigus, Eurymetopus, Floresianus, Parapantomorus, Galapaganus, Phacepholis and Symmathetes. Moreover, the phylogeny of Naupactini [2] suggests that the naupactine genera diversified in the High Andes, Paramos and Puna (Amitrus Schoenherr, Amphideritus Schoenherr, Asymmathetes Wibmer and O'Brien, Leschenius del Río, Melanocyphus Jekel, Obrieniolus del Río and Trichocyphus Heller) also belong to the Pantomorus-Naupactus complex, and might be classified in Naupactus.

We conclude that so far there is no satisfactory solution for the classification of the highly diversified weevil genus Naupactus and its relatives. One more comprehensive taxon sampling and new molecular evidence will contribute to essential information for a more definite conclusion. Until then, we prefer to maintain Naupactus as non-monophyletic and to accommodate the remaining species in species groups, subgroups or genera useful for further evolutionary or biogeographic studies (see [1]), thereby avoiding the creation of unnecessary generic names.

Classification should serve as a general reference system, endowed with explanatory, predictive and heuristic properties providing foundation for all comparative studies in biology [60]. The field of Phylogenetic Systematics [61] has greatly benefited from the use of molecular markers and, more recently, of genomic data, all of which have given rise to novel hypotheses on the evolution of animals and plants [62-65]. However, there is an increasing gap between phylogenetic analyses and classifications based on Linnaean nomenclature, probably because of the difficulties in translating monophyletic groups inferred from molecular phylogenetic signals into words [66]. In addition, there are many other issues affecting final results, such as the poorly known morphology of several taxa that are yet to be revised, genealogies resulting from insufficient taxon samplings, and the effect that the absence of some terminal taxa may have on phylogenetic hypotheses; the fact that a single tree may result in more than one classification, even if it represents a robust phylogenetic hypothesis; and a potential conflict between the dynamic nature of phylogenetic analysis and the desirable stability of the Linnaean Classification and Nomenclature. In the case of hyperdiverse groups of animals, such as weevils, the reduction of the gap between Phylogeny and Classification will take a time. Meanwhile, we attempt to shed light on the evolution of particularly complex taxa, such as the genus Naupactus, while being conscious of nomenclatural decisions.

\subsection{Taxonomic Amendments}

In order to address the taxonomic implications of our phylogenetic results, we propose the following nomenclatural changes, relative to Wibmer and O'Brien [13] and Alonso-Zarazaga and 
Lyal [3]: (i) to transfer the species Naupactus inermis to the genus Lanterius; (ii) to transfer the species Naupactus setarius to the genus Symmathetes.

Lanterius inermis (Hustache), new combination.

Symmathetes setarius (Boheman) new combination.

Supplementary Materials: The following data is available online at http:/ /www.mdpi.com/1424-2818/10/3/ 59/s1, Table S1: Morphological data matrix.

Author Contributions: Conceptualization, M.G.d.R. and A.A.L.; Data curation, M.G.d.R., M.S.R., V.A.C. and A.A.L.; Formal analysis, M.G.d.R., M.S.R. and A.A.L.; Methodology, M.S.R. and V.A.C.; Writing-original draft, M.G.d.R. and A.A.L.; Writing—review \& editing, M.G.d.R., M.S.R., V.A.C. and A.A.L.

Funding: This research received financial funding of Consejo Nacional de Investigaciones Científicas y Técnicas (CONICET), the Agencia Nacional de Promoción Científica y Tecnológica (ANPCYT) and the Universidad Nacional de La Plata UNLP (grants CONICET-IBOL 2318/11, BID-PICT 2012/2524, 2016/2798, 2016/0739 and 11/N852).

Acknowledgments: We thank Paulina Hernández for her help in the technical work with the photographs; Silvia Pietrovsky for her assistance in the English language editing; the "Centre for biodiversity Genomics", University of Guelph for the COI sequences; and the reviewers and editors for their helpful suggestions to improve the manuscript.

Conflicts of Interest: The authors declare no conflicts of interest.

\section{References}

1. Del Río, M.G.; Morrone, J.J.; Lanteri, A.A. Evolutionary biogeography of South American weevils of the tribe Naupactini (Coleoptera: Curculionidae). J. Biogeogr. 2015, 42, 1293-1304. [CrossRef]

2. Lanteri, A.A.; del Río, M.G. Phylogeny of the tribe Naupactini (Coleoptera: Curculionidae) based on morphological characters. Syst. Entomol. 2017, 42, 429-447. [CrossRef]

3. Alonso-Zarazaga, M.A.; Lyal, C.H.C. A World Catalogue of Families and Genera of Curculionoidea: (Insecta: Coleoptera) Excepting Scolytidae and Platypodidae; Entomopraxis, D.C.P.: Barcelona, Spain, 1999; ISBN 978-84-605-9994-4.

4. Lanteri, A.A. Systematic revision and cladistic analysis of Phacepholis Horn (Coleoptera: Curculionidae). Southwest. Entomol. 1990, 15, 179-204.

5. Lanteri, A.A. Systematic revision of Ericydeus Pascoe (Coleoptera: Curculionidae). Entomol. Scand. 1995, 26, 393-424. [CrossRef]

6. Schoenherr, C.J. Genera et Species Curculionidum, cum Synonymia hujus Famili; Roret: Paris, France, 1833; Volume 1, pp. I-XV, 1-381, 383-681.

7. Schoenherr, C.J. Genera et Species Curculionidum, cum Synonymia hujus Famili; Roret: Paris, France, 1840; Volume 6, pp. I, 1-474.

8. Sharp, D.; Champion, G.C. Biologia Centrali-Americana; Taylor \& Francis: London, UK, 1889-1911; Volume IV, part 3; p. vi-354.

9. Hustache, A. Naupactini de l'Argentine et des régions limitrophes (Col. Curculion.). Rev. Soc. Entomol. Argent. $1947,13,3-146$.

10. Lanteri, A.A.; Marvaldi, A.E. Graphognathus Buchanan, a new synonym of Naupactus Dejean, and systematics of the N. leucoloma species group (Coleoptera: Curculionidae). Coleopt. Bull. 1995, 49, 206-228.

11. Bordón, C. El género Naupactus Dejean (Coleoptera: Curculionidae) en Venezuela. Acta Biológica Venezuelica $1997,17,11-51$.

12. Morrone, J.J. The species of Entiminae ranged in America south of the United States. Anales del Instituto de Biología Serie Zoología 1999, 70, 99-168.

13. Wibmer, G.J.; O'Brien, C.W. Annotated checklist of the weevils (Curculionidae sensu lato) of South America (Coleoptera: Curculionoidea). Mem. Am. Entomol. Inst. 1986, 39, 1-563.

14. O'Brien, C.W.; Wibmer, G.J. Annotated checklist of the weevils (Curculionidae sensu lato) of North America, Central America and the West Indies (Coleoptera: Curculionoidea). Mem. Am. Entomol. Inst. 1982, 34, 1-382.

15. Scataglini, M.A.; Lanteri, A.A.; Confalonieri, V.A. Phylogeny of the Pantomorus-Naupactus complex based on morphological and molecular data (Coleoptera: Curculionidae). Cladistics 2005, 21, 131-142. [CrossRef] 
16. Rosas-Echeverría, M.V.; Morrone, J.J.; del Río, M.G.; Lanteri, A.A. Phylogenetic analysis of the Pantomorus-Naupactus complex (Coleoptera: Curculionidae: Entiminae) from North and Central America. Zootaxa 2011, 2780, 1-19.

17. Buchanan, L.L. The Species of Pantomorus of America North of Mexico; United States Department of Agriculture: Washington, DC, USA, 1939; Volume 34, pp. 1-39.

18. Lanteri, A.A.; O'Brien, C.W. Taxonomic revision and cladistic analysis of Atrichonotus Buchanan (Coleoptera: Curculionidae). Trans. Am. Entomol. Soc. 1990, 116, 697-725.

19. Lanteri, A.A.; del Río, M.G. Caracteres genitales de la hembra en la clasificación y filogenia de la tribu Naupactini (Coleoptera: Curculionidae). In Contribuciones Taxonómicas en Órdenes de Insectos Hiperdiversos; Llorente Bousquets, J., Lanteri, A.A., Eds.; UNAM-RIBES-CYTED: Mexico city, Mexico, 2008; pp. 159-176.

20. Rosas, M.V.; del Río, M.G.; Lanteri, A.A.; Morrone, J.J. Track analysis of the North and Central American species of the Pantomorus-Naupactus complex (Coleoptera: Curculionidae). J. Zool. Syst. Evol. Res. 2011, 49, 309-314. [CrossRef]

21. Lanteri, A.A.; del Río, M.G. Naupactus xanthographus (Germar) species group (Curculionidae: Entiminae: Naupactini): A comprehensive taxonomic treatment. J. Nat. Hist. 2017, 51, 1557-1587.

22. Marvaldi, A.E.; Lanteri, A.A.; del Río, M.G.; Oberprieler, R.G. 3.7.5. Entiminae Schoenherr, 1823. In Handbook of Zoology. Coleoptera, Beetles. Morphology and Systematics, Vol. 3; Leschen, R.A., Beutel, R.G., Eds.; De Gruyter: Berlin, Germany; Boston, MI, USA, 2014; Volume 3, pp. 503-522.

23. Bold Systems v4. Available online: http:/ / www.boldsystems.org/ (accessed on 4 May 2018).

24. Marvaldi, A.E.; del Río, M.G.; Pereyra, V.A.; Rocamundi, N.; Lanteri, A.A. A combined molecular and morphological approach to explore higher phylogenetics of entimine weevils with special reference to South American taxa. Diversity 2018. under review.

25. Sequeira, A.; Lanteri, A.A.; Scataglini, M.A.; Confalonieri, V.A.; Farrell, B. Are flightless Galapaganus weevils older than the Galápagos Islands they inhabit? Heredity 2000, 85, 20-29. [CrossRef] [PubMed]

26. Rodriguero, M.S.; Lanteri, A.A.; Confalonieri, V.A. Speciation in the asexual realm: Is the parthenogenetic weevil Naupactus cervinus a complex of species in statu nascendi? Mol. Phylogenet. Evol. 2013, 68, 644-656. [CrossRef] [PubMed]

27. Elias-Costa, A.J.; Confalonieri, V.A.; Lanteri, A.A.; Rodriguero, M.S. Game of Clones: Is Wolbachia inducing speciation in a weevil with a mixed reproductive mode? Mol. Phylogenet. Evol. 2018. under review.

28. Sunnucks, P.; Hales, D.F. Numerous transposed sequences of mitochondrial cytochrome oxidase I-II in aphids of the genus Sitobion (Hemiptera: Aphididae). Mol. Biol. Evol. 1996, 13, 510-524. [CrossRef] [PubMed]

29. Normark, B.B. Phylogeny and Evolution of Parthenogenesis in the Aramigus tessellatus Complex (Coleoptera: Curculionidae). Ph.D. Thesis, Cornell University, Ithaca, NY, USA, 1994.

30. Bensansson, D.; Zhang, D.; Hewitt, G.M. Frequent assimilation of mitochondrial DNA by grasshopper nuclear genomes. Mol. Biol. Evol. 2000, 17, 406-415. [CrossRef] [PubMed]

31. Tamura, K.; Peterson, D.; Peterson, N.; Stecher, G.; Nei, M.; Kumar, S. MEGA5: Molecular evolutionary genetics analysis using maximum likelihood, evolutionary distance, and maximum parsimony methods. Mol. Biol. Evol. 2011, 28, 2731-2739. [CrossRef] [PubMed]

32. Lunt, D.H.; Zhand, D.X.; Szymura, J.M.; Hewitt, G.M. The insect cytochrome oxidase I gene evolutionary patterns and conserved primers for phylogenetic studies. Insect Mol. Biol. 1996, 5, 153-165. [CrossRef] [PubMed]

33. Sorenson, M.D.; Fleischer, R.C. Multiple independent transposition of mitochondrial DNA control region sequences to the nucleus. Proc. Natl. Acad. Sci. USA 1996, 93, 15239-15243. [CrossRef] [PubMed]

34. Zhang, D.X.; Hewitt, G.M. Nuclear integrations: Challenges for mitochondrial DNA markers. Trends Ecol. Evol. (Amst.) 1996, 11, 247-251. [CrossRef]

35. Thompson, J.D.; Higgins, D.G.; Gibson, T.J. CLUSTAL W: Improving the sensitivity of progressive multiple sequence alignment through sequence weighting, position specific gap penalties and weight matrix choice. Nucleic Acids Res. 1994, 22, 4673-4680. [CrossRef] [PubMed]

36. Goloboff, P.A.; Catalano, S. TNT version 1.5, including full implementation of phylogenetic morphometrics. Cladistics 2016, 32, 221-238. [CrossRef]

37. Felsenstein, J. Confidence Limits on Phylogenies: An Approach Using the Bootstrap. Evolution 1985, 39, 783-791. [CrossRef] [PubMed] 
38. Kluge, A.G.; Farris, J.S. Quantitative phyletics and the evolution of anurans. Syst. Biol. 1969, 18, 1-32. [CrossRef]

39. Farris, J.S. The retention index and the rescaled consistency index. Cladistics 1989, 5, 417-419. [CrossRef]

40. Bouckaert, R.; Heled, J.; Kühnert, D.; Vaughan, T.; Wu, C.H.; Xie, D.; Suchard, M.A.; Drummond, A.J. BEAST 2: A Software Platform for Bayesian Evolutionary Analysis. PLoS Comput. Biol. 2014, 10, e1002537. [CrossRef] [PubMed]

41. Miller, M.A.; Pfeiffe, W.; Schwartz, T. Creating the CIPRES Science Gate way for inference of large phylogenetic trees. In Proceedings of the Gateway Computing Environments Workshop (GCE), New Orleans, LA, USA, 14 November 2010; Towns, J., Ed.; IEEE: New Orleans, LA, USA, 2010.

42. Darriba, D.; Taboada, G.L.; Doallo, R.; Posada, D. jModelTest 2: More models, new heuristics and parallel computing. Nat. Methods 2012, 9, 772. [CrossRef] [PubMed]

43. Burnham, K.P.; Anderson, D.R. Model Selection and Multimodel Inference: A Practical Information-Theoretic Approach; Springer Science \& Business Media: New York, NY, USA, 2002.

44. Drumond, A.J.; Rambaut, A. BEAST: Bayesian evolutionary analysis by sampling trees. BMC Evol. Biol. 2007, 7, 214. [CrossRef] [PubMed]

45. Rambaut, A. FigTree v. 1.3.1. Computer Program and Documentation Distributed by the Author, 2006-2012. Available online: http:/ / tree.bio.ed.ac.uk/software/ (accessed on 21 December 2017).

46. Lanteri, A.A. Revisión de las especies argentinas del género Macrostylus Boheman, subgénero Mimographus Schoenherr (Coleoptera: Curculionidae). CIPFE-CED Orione Contribuciones en Biología 1985, 12, 1-6.

47. Normark, B.B.; Lanteri, A.A. Incongruence between morphological and mitochondrial DNA characters suggests hybrid origins of parthenogenetic weevil lineages (genus Aramigus). Syst. Biol. 1998, 47, 475-494. [CrossRef] [PubMed]

48. Lanteri, A.A.; del Río, M.G.; Rodriguero, M.; Confalonieri, V. Weevils of the Pantomorus-Naupactus complex: Cladistics and generic classification. Cladistics 2010, 26, 214.

49. Del Río, M.G.; Lanteri, A.A.; Guedes, J.V.C. Taxonomic revision and cladistic analysis of Teratopactus Heller (Coleoptera: Curculionidae). Invertebr. Syst. 2006, 20, 585-602. [CrossRef]

50. Lanteri, A.A. Revisión del género Asynonychus Crotch (Coleoptera: Curculionidae). Rev. Asoc. Cs. Nat. Litoral. 1986, 2, 161-174. [CrossRef]

51. Blackwelder, R.E. Checklist of the Coleopterous insects of Mexico, Central America, the West Indies and South America. Part 5. Bull. U. S. Natl. Mus. 1947, 185, 765-925. [CrossRef]

52. Lanteri, A.A.; Díaz, N.B. Systematic study and cladistic analysis of the genus Aramigus Horn (Coleoptera: Curculionidae). Trans. Am. Entomol. Soc. 1994, 120, 113-144.

53. Lanteri, A.A. Systematics, cladistics and biogeography of a new weevil genus Galapaganus (Coleoptera: Curculionidae) from the Galápagos Islands, and coasts of Ecuador and Perú. Trans. Am. Entomol. Soc. 1992, 118, 227-267.

54. Lanteri, A.A. New Taxonomic and Biogeographic Information on Galapaganus femoratus species group (Coleoptera: Curculionidae: Entiminae). Trans. Am. Entomol. Soc. 2004, 130, 177-192.

55. Lanteri, A.A.; Morrone, J.J. Cladistics of the Naupactus leucoloma species group, Atrichonotus, and Eurymetopus (Coleoptera: Curculionidae). Revista de la Sociedad Entomológica Argentina 1995, 54, 99-112.

56. Lanteri, A.A.; Normark, B.B. Parthenogenesis in the tribe Naupactini (Coleoptera: Curculionidae). Ann. Entomol. Soc. Am. 1995, 88, 722-731. [CrossRef]

57. Lanteri, A.A. Revisión sistemática del género Eurymetopus Schoenherr (Coleoptera: Curculionidae) mediante la aplicación de técnicas numéricas. Revista de la Sociedad Entomológica Argentina 1984, 43, 247-281.

58. Sequeira, A.; Sijapati, M.; Lanteri, A.; Roque Albelo, L. Nuclear and mitochondrial sequences confirm complex colonization patterns and clear species boundaries for flightless weevils in the Galapagos archipelago. Philos. Trans. R. Soc. Lond. B Biol. Sci. 2008, 363, 3439-3451. [CrossRef] [PubMed]

59. Sequeira, A.S.; Lanteri, A.A.; Albelo, L.R.; Bhattacharya, S.; Sijapati, M. Colonization history, ecological shifts and diversification in the evolution of endemic Galápagos weevils: Colonization and diversification of Galápagos weevils. Mol. Ecol. 2008, 17, 1089-1107. [CrossRef] [PubMed]

60. Mayr, E. Principles of Systematic Zoology; McGraw-Hill: New York, NY, USA, 1969.

61. Hennig, W. Phylogenetic Systematics; University of Illinois Press: Urbana, IL, USA, 1966. 
62. Marvaldi, A.E.; Sequeira, A.S.; O’Brien, C.W.; Farrell, B.D. Molecular and Morphological Phylogenetics of Weevils (Coleoptera, Curculionoidea): Do Niche Shifts Accompany Diversification? Syst. Biol. 2002, 51, 761-785. [CrossRef] [PubMed]

63. Jordal, B.H.; Sequeira, A.S.; Cognato, A.I. The age and phylogeny of wood boring weevils and the origin of subsociality. Mol. Phylogenet. Evol. 2011, 59, 708-724. [CrossRef] [PubMed]

64. Gunter, N.L.; Oberprieler, R.G.; Cameron, S.L. Molecular phylogenetics of Australian weevils (Coleoptera: Curculionoidea): Exploring relationships in a hyperdiverse lineage through comparison of independent analyses. Austral Entomol. 2016, 55, 217-233. [CrossRef]

65. Shin, S.; Clarke, D.J.; Lemmon, A.R.; Moriarty Lemmon, E.; Aitken, A.L.; Haddad, S.; Farrell, B.D.; Marvaldi, A.E.; Oberprieler, R.G.; McKenna, D.D. Phylogenomic Data Yield New and Robust Insights into the Phylogeny and Evolution of Weevils. Mol. Biol. Evol. 2018, 35, 823-836. [CrossRef] [PubMed]

66. Franz, N.M. On the lack of good scientific reasons for the growing phylogeny/classification gap. Cladistics 2005, 21, 495-500. [CrossRef]

(C) 2018 by the authors. Licensee MDPI, Basel, Switzerland. This article is an open access article distributed under the terms and conditions of the Creative Commons Attribution (CC BY) license (http://creativecommons.org/licenses/by/4.0/). 